\title{
Aerosol properties over the western Mediterranean basin: temporal and spatial variability
}

\author{
H. Lyamani ${ }^{1,2}$, A. Valenzuela ${ }^{1,2}$, D. Perez-Ramirez ${ }^{3,4}$, C. Toledano ${ }^{5}$, M. J. Granados-Muñoz ${ }^{1,2}$, F. J. Olmo ${ }^{1,2}$, and \\ L. Alados-Arboledas ${ }^{1,2}$ \\ ${ }^{1}$ Andalusian Institute for Earth System Research (IISTA-CEAMA), 18006, Granada, Spain \\ ${ }^{2}$ Department of Applied Physic, University of Granada, 18071, Granada, Spain \\ ${ }^{3}$ Mesoscale Atmospheric Processes Laboratory, NASA Goddard Space Flight Center, Greenbelt, Maryland 20771, USA \\ ${ }^{4}$ Goddard Earth Sciences Technology and Research, Universities Space Research Association (GESTAR/USRA), Columbia, \\ Maryland, USA \\ ${ }^{5}$ Atmospheric Optics Group (GOA), University of Valladolid (UVA), 47071, Valladolid, Spain
}

Correspondence to: H. Lyamani (hlyamani@ugr.es)

Received: 1 July 2014 - Published in Atmos. Chem. Phys. Discuss.: 21 August 2014

Revised: 2 February 2015 - Accepted: 15 February 2015 - Published: 5 March 2015

\begin{abstract}
This study focuses on the analysis of Aerosol Robotic Network (AERONET) aerosol data obtained over Alborán Island $\left(35.90^{\circ} \mathrm{N}, 3.03^{\circ} \mathrm{W}, 15 \mathrm{~m}\right.$ a.s.l.) in the western Mediterranean from July 2011 to January 2012. Additional aerosol data from the three nearest AERONET stations (Málaga, Oujda and Palma de Mallorca) and the Maritime Aerosol Network (MAN) were also analyzed in order to investigate the temporal and spatial variations of aerosol over this scarcely explored region. High aerosol loads over Alborán were mainly associated with desert dust transport from North Africa and occasional advection of anthropogenic fine particles from central European urban-industrial areas. The fine particle load observed over Alborán was surprisingly similar to that obtained over the other three nearest AERONET stations, suggesting homogeneous spatial distribution of fine particle loads over the four studied sites in spite of the large differences in local sources. The results from MAN acquired over the Mediterranean Sea, Black Sea and Atlantic Ocean from July to November 2011 revealed a pronounced predominance of fine particles during the cruise period.
\end{abstract}

\section{Introduction}

Atmospheric aerosol particles play an important role in the atmosphere because they can affect the Earth's radiation budget directly by the scattering and absorption of solar and terrestrial radiation (e.g., Haywood and Shine, 1997), and indirectly by modifying cloud properties (e.g., Kaufman et al., 2005), and hence have important climate implications. Understanding the influence of atmospheric aerosols on radiative transfer in the atmosphere requires accurate knowledge of their columnar properties, such as the spectral aerosol optical depth, a property related to aerosol amount in atmospheric column (Haywood and Boucher, 2000; Dubovik et al., 2002). Global measurements of columnar aerosol properties including spectral aerosol optical depth can be assessed from satellite platforms (e.g., Kaufman et al., 1997). However, satellite aerosol retrievals suffer from large errors due to uncertainties in surface reflectivity. Currently, the ground sun photometric technique is considered the most accurate one for the retrieval of aerosol properties in the atmospheric column (e.g., Estellés et al., 2012). Thus, many ground-based observation networks have been established in order to understand the optical and radiative properties of aerosols and indirectly evaluate their effect on the radiation budget and climate (e.g., AERONET (Aerosol Robotic Network)). However, the quantification of aerosol effects is very difficult because of the high spatial and temporal variability of phys- 
ical and optical properties of aerosol (Forster et al., 2007). This high aerosol variability is due to their short atmospheric lifetime, aerosol transformations, aerosol dynamics, different meteorological characteristics, and the wide variety of aerosol sources (Haywood and Boucher, 2000; Dubovik et al., 2002). In this sense, Forster et al. (2007) highlighted the large uncertainties on the aerosol impact on radiation budget. Therefore, monitoring of aerosol properties at different areas in the world can contribute to reduce these uncertainties.

Most of the planet is covered by oceans and seas, and thus the study of marine aerosol is a topic of ongoing interest (e.g., Smirnov et al., 2002). Particularly, many efforts are being made to characterize this aerosol type from groundbased measurements, leading to the creation of the Maritime Aerosol Network (MAN) as part of the AERONET network (Smirnov et al., 2009). However, MAN lacks of continuous temporal measurements, and thus measurements from remote islands in the oceans and seas are required. Particularly, in the Mediterranean basin aerosol properties are characterized by a great complexity, due to the presence of different types of aerosols such as maritime aerosols from the Mediterranean Sea itself, biomass burning aerosols from forest fires, anthropogenic aerosols transported from European and North African urban areas, mineral dust originated from north African arid areas, and anthropogenic particles emitted from the intense ship traffic in the Mediterranean Sea (e.g., Lelieveld et al., 2002; Barnaba and Gobbi, 2004; Lyamani et al., 2005, 2006a, b; Papadimas et al., 2008; Viana et al., 2009; Pandolfi et al., 2011; Alados-Arboledas et al., 2011; Becagli et al., 2012; Valenzuela et al., 2012a, b; Mallet et al., 2013). Past studies revealed that the aerosol load and the aerosol direct radiative effect over the Mediterranean are among the highest in the world, especially in summer (e.g., Lelieveld et al., 2002; Markowicz et al., 2002; Papadimas et al., 2012; Antón et al., 2012).

In this framework, the characterization of aerosol over the Mediterranean has received great scientific interest. To date, a large number of studies has been done focusing on the eastern and central regions (e.g., Formenti et al., 1998; Balis et al., 2003; Gerasopoulos et al., 2003; Di Iorio et al., 2003; Kubilay et al., 2003; Pace et al., 2005, 2006; Fotiadi et al., 2006; Meloni et al., 2007, 2008; Di Sarra et al., 2008; Di Biagio et al., 2010; Boselli et al., 2012). However, few studies have been done in the western Mediterranean Basin (Horvath et al., 2002; Alados-Arboledas et al., 2003; Mallet et al., 2003; Estellés et al., 2007; Saha et al., 2008; Pérez-Ramírez et al., 2012, Foyo-Moreno et al., 2014). The majority of these studies have been performed in coastal Mediterranean urban sites largely influenced by local pollution emissions, except those carried out at Crete and Lampedusa islands in the eastern and central Mediterranean Sea regions. In general, columnar aerosol data are scarce over the Mediterranean Sea and almost absent over the western Mediterranean Sea. Thus, measurements of the aerosol properties over the western Mediterranean Sea are needed in order to evaluate the aerosol regimes over this scarcely explored region (Smirnov et al., 2009). In order to fill this gap and provide columnar aerosol properties over the western Mediterranean Sea, the Atmospheric Physic Group of the University of Granada, Spain, in collaboration with Royal Institute and Observatory of the Spanish Navy (ROA), has installed a sun photometer at Alborán, a very small island in the westernmost part of Mediterranean Sea located midway between the African and European continents. Currently, this station is part of AERONET network (http://aeronet.gsfc.nasa.gov).

This study focuses on the characterization of aerosol load and aerosol types as well as on their temporal variability over Alborán Island in the western Mediterranean from 1 July 2011 to 23 January 2012. In addition, special attention is given to the conditions responsible for large aerosol loads over this island, and much attention is paid to identify the potential aerosol sources affecting Alborán. Furthermore, additional aerosol properties from three AERONET stations (Málaga, Oujda and Palma de Mallorca) surrounding Alborán Island and from a MAN cruise over the Mediterranean Sea, Black Sea and Atlantic Ocean (Fig. 1) are analyzed here to investigate the spatial aerosol variation over the Mediterranean basin.

The work is structured as follows. In Sect. 2 we describe the instrumentation used and the experimental sites. Section 3 is devoted to the main results, where we analyze the aerosol optical properties at Alborán Island and the spatial variability of aerosol properties in the Mediterranean. Finally, in Sect. 4 we present the summary and conclusions.

\section{Instrumentation and study sites}

\subsection{AERONET measurements}

Columnar aerosol properties were measured by a CIMEL CE-318-4 sun photometer, which is the standard automated sun photometer used in the AERONET network (Holben et al., 1998). This instrument has a full view angle of $1.2^{\circ}$ and makes direct sun measurements at 340, 380, 440, 500, 670, 870, 940 and $1020 \mathrm{~nm}$ (nominal wavelengths). The direct sun measurements are then used to retrieve the aerosol optical depth at each wavelength, $\delta_{\mathrm{a}}(\lambda)$, except for $940 \mathrm{~nm}$ which is used to compute precipitable water vapor (Holben et al.,1998). Detailed information about the CIMEL sun photometer can be found in Holben et al., 1998. The total estimated uncertainty in $\delta_{\mathrm{a}}(\lambda)$ provided by AERONET is of \pm 0.01 for $\lambda>440 \mathrm{~nm}$ and \pm 0.02 for shorter wavelengths (Holben et al., 1998). Furthermore the spectral dependency of the $\delta_{\mathrm{a}}(\lambda)$ has been considered through the Ångström exponent, $\alpha(440-870)$, calculated in the range $440-870 \mathrm{~nm}$. The Ångström exponent provides an indication of the particle size (e.g., Dubovik et al., 2002). Small values of the Ångström coefficient $(\alpha(440-870)<0.5)$ suggest a predominance of coarse particles, such as sea salt or dust, while 


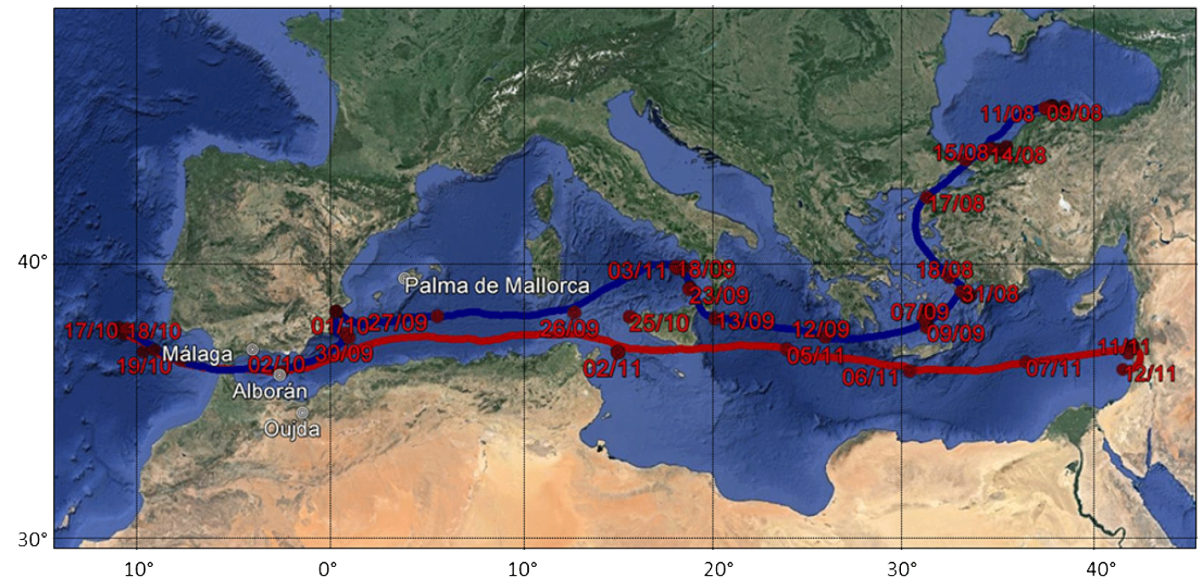

Figure 1. Map of Mediterranean basin showing the location of Alborán Island, Málaga, Oujda and Palma de Mallorca and a MAN cruise track over the Mediterranean Sea, Black Sea and Atlantic Ocean during 26 July-13 November 2011.

$\alpha(440-870)>1.5$ indicates a predominance of small particles such as sulphate, nitrate and biomass burning particles. Also included in the analysis are aerosol optical depths at $500 \mathrm{~nm}$ for fine mode $\left(\delta_{\mathrm{F}}(500 \mathrm{~nm})\right)$ and for coarse mode $\left(\delta_{\mathrm{C}}(500 \mathrm{~nm})\right)$ as well as the fine mode fraction (FMF) (ratio of $\delta_{\mathrm{F}}(500 \mathrm{~nm})$ to $\left.\delta_{\mathrm{a}}(500 \mathrm{~nm})\right)$, determined using the spectral de-convolution algorithm method developed by O'Neill et al. (2003). In this study, the level 2 AERONET aerosol data are used.

\subsection{AERONET stations}

This study focuses on the AERONET sun photometer measurements acquired at the Alborán Island $\left(35.90^{\circ} \mathrm{N}, 3.03^{\circ} \mathrm{W}\right.$, 15 ma.s.l.), in the western Mediterranean Sea, from 1 July 2011 to 23 January 2012. Alborán is a small island with an approximate surface of $7 \mathrm{ha}$, located $\sim 50 \mathrm{~km}$ north of the Moroccan coast and $90 \mathrm{~km}$ south of the Spanish coast (Fig. 1). Currently, only 12 members of a small Spanish Army garrison live on the island. The island and its surrounding area are declared a natural park and marine reserve. There is no significant local anthropogenic emission source at Alborán; however, the island is just south of an important shipping route (www.marinetraffic.com). Due to its location, Alborán Island is expected to be affected, depending on regional circulation, by anthropogenic pollutants originated in urban and industrial European areas, anthropogenic particles emitted from the ship traffic, desert dust transported from North African arid regions and maritime aerosols from the Mediterranean Sea. The climate of the region depends strongly on the Azores anticyclone. Winter is mainly characterized by low pressure systems passing over the Iberian Peninsula, resulting in the prevalence of westerly winds and enhanced rainfall. In this season, the weather is unstable, wet and windy. In summer, the well-established Azores high pressure produces dry and mild weather with easterly winds that combine with sea/land breezes created by the aridity of the coastal mountains (Sumner et al., 2001).

In addition, to investigate the spatial variation of aerosol properties over the western Mediterranean, we used AERONET data obtained from 1 July 2011 to 23 January 2012 over three AERONET stations surrounding Alborán Island; Oujda, Málaga and Palma de Mallorca (see Fig. 1). These sites cover different environments including, urban, coastal and island sites, respectively, and have different background aerosol characteristics. Palma de Mallorca $\left(39.35^{\circ} \mathrm{N}\right.$, $2.39^{\circ} \mathrm{E}, 13 \mathrm{~m}$ a.s.1.), the capital of the Balearic Islands, is the largest city in the Mallorca Island with a population of around 400000 . It is located in the western Mediterranean Sea, about $250 \mathrm{~km}$ from the African continent and $190 \mathrm{~km}$ from the Spanish coast. Málaga $\left(36.72^{\circ} \mathrm{N}, 4.5^{\circ} \mathrm{W}\right.$, $40 \mathrm{~m}$ a.s.l.), with a population of around 600000 is the major coastal city in southeast Spain on the Mediterranean coast. Oujda city $\left(34.65^{\circ} \mathrm{N}, 1.89^{\circ} \mathrm{W}, 450 \mathrm{~m}\right.$ a.g.l.) is located in eastern Morocco, $60 \mathrm{~km}$ south of the Mediterranean Sea, with an estimated population of 450000 .

\subsection{Maritime Aerosol Network measurements}

Furthermore, we used shipborne sun photometer measurements collected onboard the Nautilus 11 on the Mediterranean Sea, Atlantic Ocean and Black Sea during the period 26 July-13 November 2011. These measurements were made in the framework of the Maritime Aerosol Network (MAN), a component of AERONET (Smirnov et al., 2011). More detailed information about the Nautilus 11 cruise track can be found at http://aeronet.gsfc.nasa.gov/new_web/cruises_new/ Nautilus_11.html. MAN uses Microtops II hand-held sun photometers and utilizes calibrations and data processing procedures of AERONET network. The Microtops II sun photometer used in this cruise acquires direct sun measurements at 440, 500, 675 and $870 \mathrm{~nm}$. The estimated uncer- 
tainty of the optical depth in each channel is around \pm 0.02 (Knobelspiesse et al., 2004). Level 2 MAN data are used in this study.

\subsection{Air mass trajectories}

To characterize the transport pathways and the origins of air masses arriving at our studied AERONET sites, 5-day backward trajectories ending at 12:00 UTC at these sites for $500,1500,2500,3500,4500$ and $5000 \mathrm{~m}$ above ground level were calculated using the HYSPLIT model for days with AERONET measurements (Draxler and Rolph, 2003). In addition, backward trajectories ending at the different points of MAN cruise for 500, 1500, 2500, 3500, 4500 and $5000 \mathrm{~m}$ above ground level were also performed for days with MAN observations. The HYSPLIT model version employed uses GDAS meteorological data and includes vertical wind.

\section{Results and discussion}

\subsection{Temporal evolution of aerosol properties over Alborán Island}

Figure 2 shows the temporal evolutions of daily mean values of aerosol optical depths at 500 and $1020 \mathrm{~nm}$ and $\alpha(440$ 870) measured at Alborán Island in the western Mediterranean from 1 July 2011 to 23 January 2012. There are some gaps in $\delta_{\mathrm{a}}(\lambda)$ and $\alpha(440-870)$ data series due to some technical problems and the presence of clouds (invalid data). Table 1 presents a statistical summary of daily average values of all the analyzed aerosol properties. One of the main features observed is the large variability of $\delta_{\mathrm{a}}(\lambda)$ (for example, $\delta_{\mathrm{a}}(500 \mathrm{~nm})$ ranged from 0.03 to 0.54$)$ that is primarily related to changes in the air masses affecting the study area, as can be seen hereafter. The coefficient of variation (COV), defined as the standard deviation divided by the mean value, can be used to compare the variability of different data sets. As shown in Table 1 , the $\delta_{\mathrm{a}}(\lambda)$ at $1020 \mathrm{~nm}$ (with COV of $91 \%$ ) showed much greater variability than at $340 \mathrm{~nm}$ (with COV of $60 \%$ ). It is well known that $\delta_{\mathrm{a}}(\lambda)$ at higher wavelengths is more affected by naturally produced coarse particles (radius above $0.5 \mu \mathrm{m})$ like dust and sea salt particles, while $\delta_{\mathrm{a}}(\lambda)$ at smaller wavelengths is more sensitive to the fine particles (radius below $0.5 \mu \mathrm{m}$ ) such as those from anthropogenic activities or biomass-burning. Thus, the higher variability of $\delta_{\mathrm{a}}(\lambda)$ for larger wavelengths indicates strong variability in the coarse particle load (dust or sea salt) over Alborán Island. This result is also supported by the larger COV of $\delta_{C}(500 \mathrm{~nm})$ as compared to $\delta_{\mathrm{F}}(500 \mathrm{~nm})($ Table 1). Aerosol salt emission variations due to the wind speed variation and the changes in the frequency and intensity of dust intrusions over the island may explain the large variability in the coarse particle component and hence the large $\delta_{\mathrm{a}}(\lambda)$ variability for large wavelengths. Moreover, coarse particles have shorter residence time in the atmosphere in comparison with fine particles, which could
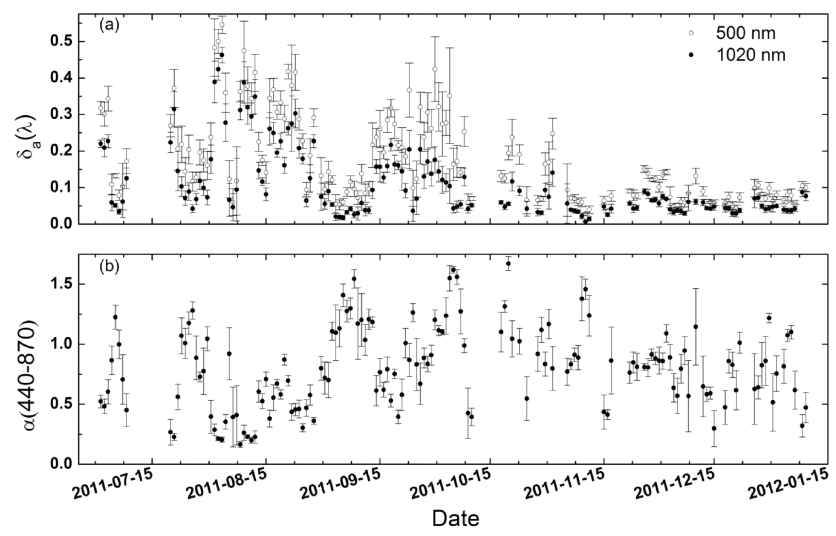

Figure 2. Temporal evolution of the daily mean values of (a) aerosol optical depth at 500 and $1020 \mathrm{~nm}$ and (b) the Ångström exponent calculated in the range $440-870 \mathrm{~nm}$, measured at Alborán Island in the western Mediterranean from 1 July 2011 to 23 January 2012. The error bars are standard deviations.

explain also the large $\delta_{C}(\lambda)$ variability. On the other hand, $\alpha(440-870)$ values also show large variability and vary from 0.2 to 1.7 with mean value of $0.8 \pm 0.5$, indicating different atmospheric conditions dominated by different aerosol types (coarse particles, fine aerosols and/or different mixtures of both coarse and fine particles). It is noted that on $70 \%$ of the analyzed days, the values of $\alpha(400-870)$ were lower than 1 , suggesting that coarse particles dominated the aerosol population over the Alborán Island for most of the analyzed days. This is further supported by the analysis of fine mode fraction which ranged from 0.20 to 0.90 (mean value of $0.47 \pm 0.15$ ), with daily mean values less than 0.5 on $65 \%$ of the analyzed days.

The observed mean $\delta_{\mathrm{a}}(500 \mathrm{~nm})$ value over Alborán Island was significantly higher (by factor of 2) than that reported by Smirnov et al. $(2002)\left(\delta_{\mathrm{a}}(500 \mathrm{~nm})\right.$ in the range $\left.0.06-0.08\right)$ for open oceanic areas in the absence of long-range transport influences. Moreover, the mean $\delta_{\mathrm{a}}(500 \mathrm{~nm})$ and $\alpha(440$ $870)$ values obtained in this study were larger than the global mean $\delta_{\mathrm{a}}(500 \mathrm{~nm})$ value of 0.11 and $\alpha(440-870)$ of 0.6 reported for maritime aerosols by Smirnov et al. (2009). On the other hand, average aerosol optical depths at $495.7 \mathrm{~nm}$ of $0.24 \pm 0.14$ and $\alpha(415-868)$ of $0.86 \pm 0.63$ were obtained from multi filter rotating shadowband radiometer at Lampedusa Island (in the central Mediterranean Sea) during July 2001-September 2003 (Pace et al., 2006). Using AERONET data measured in Crete Island (eastern Mediterranean Sea) during 2003-2004, Fotiadi et al. (2006) reported mean $\delta_{a}(500 \mathrm{~nm})$ value of 0.21 and $\alpha(440-870)$ of 1.1 . The differences between aerosol properties observed over the islands of Alborán, Lampedusa and Crete could be explained in terms of differences in the period and duration of the measurements, in air mass circulation and in the methodologies employed. Later we compare the results obtained over Alborán to those observed over three nearby AERONET sta- 
Table 1. Statistical summary of daily mean values of spectral aerosol optical depth at 1020, 500 and $340 \mathrm{~nm}$, Ångström exponent, $\alpha(440-870)$, fine and coarse mode aerosol optical depths at $500 \mathrm{~nm}, \delta_{F}(500 \mathrm{~nm})$ and $\delta_{\mathrm{C}}(500 \mathrm{~nm})$, and fine mode fraction, FMF, observed over Alborán Island in the western Mediterranean during 1 July 2011-23 January 2012; SD is the standard deviation and COV is the coefficient of variation.

\begin{tabular}{lrrrrr}
\hline & Mean & SD & Minimum & Maximum & $\operatorname{COV}(\%)$ \\
\hline$\delta_{\mathrm{a}}(1020 \mathrm{~nm})$ & 0.11 & 0.10 & 0.01 & 0.46 & 91 \\
$\delta_{\mathrm{a}}(500 \mathrm{~nm})$ & 0.17 & 0.12 & 0.03 & 0.54 & 70 \\
$\delta_{\mathrm{a}}(340 \mathrm{~nm})$ & 0.25 & 0.15 & 0.05 & 0.65 & 60 \\
$\alpha(440-870)$ & 0.8 & 0.4 & 0.2 & 1.7 & 50 \\
$\delta_{\mathrm{F}}(500 \mathrm{~nm})$ & 0.08 & 0.05 & 0.01 & 0.30 & 63 \\
$\delta_{\mathrm{C}}(500 \mathrm{~nm})$ & 0.10 & 0.09 & 0.01 & 0.4 & 90 \\
FMF & 0.47 & 0.15 & 0.20 & 0.94 & 32 \\
\hline
\end{tabular}

tions (during the same period and using the same type of instruments).

According to the Smirnov et al. (2003) criterion, pure maritime situations can be generally found when $\delta_{\mathrm{a}}(500 \mathrm{~nm})<0.15$ and $\alpha(440-870)$ is less than 1 . Considering this criterion, pure maritime situations were observed over Alborán Island on $40 \%$ of the analyzed days. According to back trajectory analysis, almost all these days were characterized by advection of clean Atlantic air masses over the study area. In addition, the majority of these pure maritime cases were observed during the wet season from November to January. This result is in agreement with the study performed at the island of Lampedusa, in the central Mediterranean, showing that pure maritime situations are usually observed during Atlantic air advection (Pace et al., 2006). However, clean maritime conditions observed over Alborán Island during the analyzed period are more frequent than those observed over Lampedusa. Pace et al. (2006) showed that clean maritime conditions are rather rare over the central Mediterranean due to the large impact of natural and anthropogenic sources. The difference in the occurrences of clean maritime conditions at these two sites can be explained by their different locations. Alborán is closer to the Atlantic Ocean than Lampedusa is, and the Atlantic air masses reaching Lampedusa may be influenced more by anthropogenic aerosol during their passage over Mediterranean Sea and continents.

Threshold values for $\delta_{\mathrm{a}}(500 \mathrm{~nm})$ and $\alpha(440-870)$ have been widely used in remote sensing to identify marine aerosol type. For example, Smirnov et al. (2003) used $\delta_{\mathrm{a}}(500 \mathrm{~nm}) \leq 0.15$ and $\alpha(440-870) \leq 1$ and Sayer et al. $(2012 \mathrm{a}, \mathrm{b})$ proposed $\delta_{a}(500 \mathrm{~nm}) \leq 0.2$ and $0.2 \leq \alpha(440$ $870) \leq 1$ while Toledano et al. (2007) used $\delta_{\mathrm{a}}(500 \mathrm{~nm}) \leq 0.15$ and $\alpha(440-870) \leq 0.6$ for identifying pure maritime situations. However, the proposed threshold values for $\delta_{\mathrm{a}}(500 \mathrm{~nm})$ and $\alpha(440-870)$ to identify maritime aerosol type are purely empirical. Therefore, not all observations that meet these thresholds will represent the pure maritime aerosol. In fact, in Alboran Island we found measurements that fulfill these criteria but that are not associated with pure maritime conditions. In this sense, in Fig. 3 we show the $\delta_{a}(500 \mathrm{~nm})$ and $\alpha(440-870)$ observed on 26 August, 2011. During this day, the $\delta_{\mathrm{a}}(500 \mathrm{~nm})$ values ranged from 0.06 to 0.13 with mean daily value of $0.09 \pm 0.01$ and $\alpha(440-870)$ was in the range $0.3-0.6$, indicating clean atmospheric condition dominated by coarse particles. Thus, according to the above criteria this day is classified as pure maritime case. However, the back trajectory analysis and Meteosat Second Generation (MSG) satellite image (Thieuleux et al., 2005) for 26 August revealed the presence of dust over Alborán Island (Fig. 3). Therefore, care must be taken when using $\delta_{\mathrm{a}}(500 \mathrm{~nm})$ and $\alpha(440-870)$ thresholds for discriminating the pure maritime cases since dusty situations with low dust loads can be confused with pure maritime conditions. Additional information such as air mass back trajectory or satellite images is needed for better identifying the pure maritime cases.

As can be seen in Fig. 2, there were several days strongly influenced by aerosols, with $\delta_{\mathrm{a}}(500 \mathrm{~nm})$ values exceeding 0.3 . High aerosol loads $\left(\delta_{\mathrm{a}}(500 \mathrm{~nm})>0.3\right)$ over Alborán Island were observed on 30 of the 160 analyzed days. All these events were observed from July to October. In 27 of these cases, the mean daily $\alpha(440-870)$ values were lower than 0.8 and fine mode fraction (FMF) lower than 0.5; suggesting predominance of coarse particles as either sea salt or dust transported from desert areas. According to the analyses of back trajectories and MODIS satellite images (not shown), all these 27 cases were related to dust intrusions from North Africa. It is important to note that in these dust events, the $\delta_{F}(500 \mathrm{~nm})$ values were also relatively high (for this remote site) and ranged from 0.07 to 0.20 with mean value of $0.12 \pm 0.03$. These results highlight a considerable contribution of fine mode particles (either dust or anthropogenic or both) to the aerosol population (FMF ranged from 20 to $52 \%$ ) during these dust events. Back trajectory analysis for dusty days with highest fine aerosol load revealed that the air masses reaching the study area at low levels (at 500 or $1500 \mathrm{~m}$ level) have originated over Europe and the Mediterranean Sea. However, during desert dust events with lowest fine aerosol loads, none of the air masses affecting the study area come from Europe or Mediterranean Sea, which points out significant contribution of anthropogenic particles to the fine mode fraction of $\delta_{a}(500 \mathrm{~nm})$ during desert dust events associated with large loads of fine aerosol particles.

The remaining high aerosol load events were observed from 30 September to 4 October 2011 (Fig. 4). During these days, the high aerosol loads were associated with relatively high $\alpha(440-870)$ values that reached the highest $\alpha(440-870)$ value (about 1.6) during the entire study on 4 October. During these days, the $\delta_{\mathrm{F}}(500 \mathrm{~nm})$ values were also high (>0.19) and reached the highest mean daily value of 0.33 on 4 October. This behavior suggests a predominance of fine particles transported from continental industrial/urban areas as there is no local anthropogenic activity in Alborán. The high $\delta_{\mathrm{a}}(\lambda)$ values observed in this event were associated with persis- 

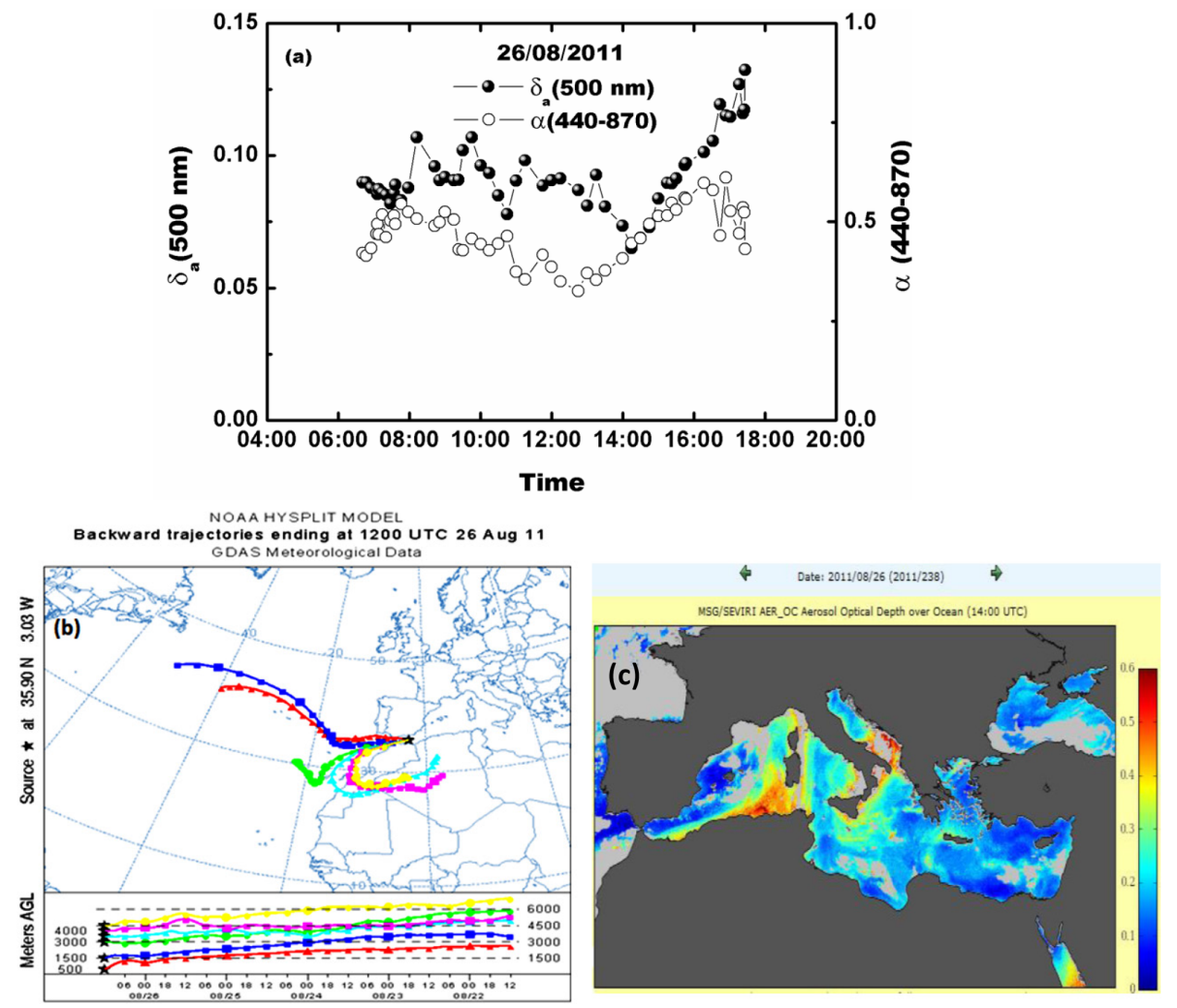

Figure 3. (a) Aerosol optical depth at $500 \mathrm{~nm}$ and Ångstrom exponent in the range 440-870 nm, (b) backward trajectories ending at 12 UTC over Alborán Island at height altitudes of 500, 1500, 3000 and 4000 m, (c) MSG satellite image for 26 August 2011 (http://www.icare. univ-lille1.fr).

tent intense high pressure systems centered over the Azores, which favor transport of anthropogenic particles emitted in Europe to Alborán Island. Indeed, on this day the air mass ending at $1500 \mathrm{~m}$ a.g.l. (Fig. 4c) came from central Europe and traveled at low altitude on the last 3 days before its arrival at Alborán Island, over an area with a great sulfate surface concentration according to Navy Aerosol Analysis and Prediction System (NAAPS) model (Fig. 4d, f). Therefore, these air masses might pick up fine anthropogenic particles in their way to Alborán Island, which may explain the high values of both $\delta_{\mathrm{a}}(500 \mathrm{~nm})$ and $\alpha(440-870)$ parameters observed during this event. Thus, the desert dust transport appears to be a main cause of high aerosol loads while transport from central European urban areas is associated with occasional large aerosol loads over Alboran Island. These results are in accordance with those reported by Fotiadi et al. (2006) for Crete, who found the highest values of $\delta_{\mathrm{a}}(\lambda)$ primarily during southeasterly winds, associated with coarse dust aerosols, and to a lesser extent to northwesterly winds associated with fine aerosols originated in urban industrial European areas.

\subsection{Monthly variation of aerosol properties over Alborán Island}

Figure 5 shows the monthly mean values of $\delta_{\mathrm{a}}(500 \mathrm{~nm})$, $\delta_{F}(500 \mathrm{~nm})$ and $\delta_{\mathrm{C}}(500 \mathrm{~nm})$ as well as $\alpha(440-870)$ and FMF with the corresponding standard deviations for the analyzed period. The monthly average data are calculated from daily averaged data. The largest values of $\delta_{\mathrm{a}}(500 \mathrm{~nm})$, reflecting high aerosol load, were observed during July-October while the lowest values (0.06-0.08) were measured from November to January (Fig. 5a). On the other hand, the monthly mean values of $\alpha(440-870)$ and FMF were lower than 1.0 and 0.5 respectively, indicating a relatively high abundance of coarse particles in each month of the analyzed period, except in October (Fig. 5b). For October, the mean $\alpha(440-870)$ was $1.1 \pm 0.4$ and the FMF $0.63 \pm 0.20$, indicating an increase in fine particle contribution during this month (Fig. 5b). It is also worth noting that both $\delta_{\mathrm{F}}(500 \mathrm{~nm})$ and $\delta_{C}(500 \mathrm{~nm})$ showed a pronounced increase during July-October, suggesting increased loads of both fine and coarse particles during these months (Fig. 5a). Moreover, $\delta_{\mathrm{C}}(500 \mathrm{~nm})$ reached its maximum in August while $\delta_{\mathrm{F}}(500 \mathrm{~nm})$ peaked in October (Fig. 5a). 

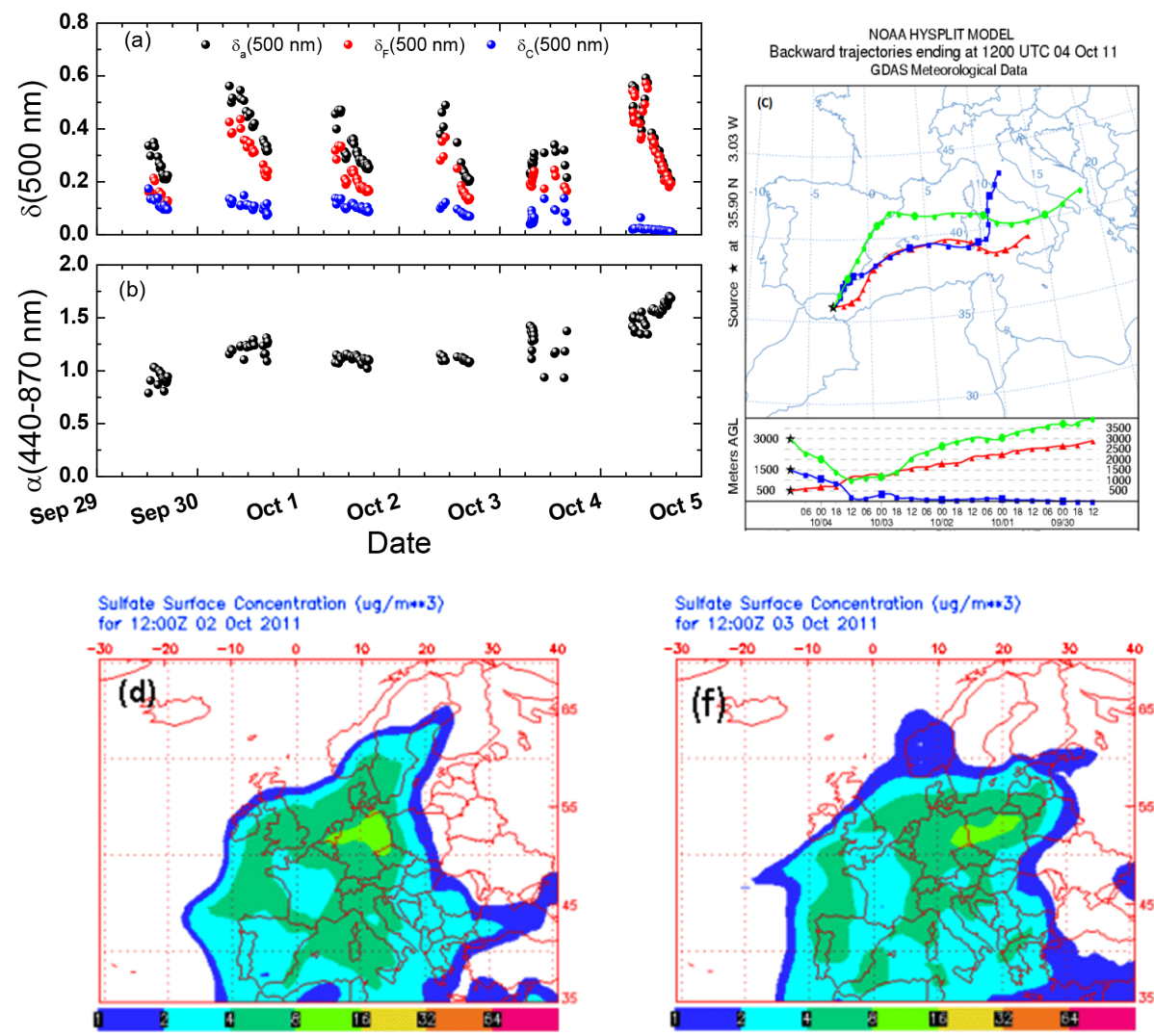

Figure 4. (a) Total, fine and coarse aerosol optical depths at $500 \mathrm{~nm}$ and (b) Ångstrom exponent in the range 440-870 nm obtained at Alborán Island during 29 September-5 October 2011. (c) Backward trajectories ending at 12:00 UTC on 4 October 2011 over Alborán Island at altitudes of 500, 1500 and $3000 \mathrm{~m}$. (d) and (f) NAAPS maps for sulfate surface concentrations for 2 and 3 October 2011 at 12:00 UTC

This pronounced change in aerosol loads from summer to winter in 2011 is primarily due to the seasonal change in atmospheric circulation over the Mediterranean (Fig. 5c). The increased coarse aerosol load observed during July-October was associated with the high frequency of desert dust intrusions in summer in comparison to November-January (Fig. 5c). In fact, 40, 70, 41 and $14 \%$ of measurement days in July, August, September and October were associated with Saharan dust intrusions, while in November-January there was no Saharan dust intrusion (Fig. 5c). Moreover, the air mass recirculation over the western Mediterranean especially in summer (Millan et al., 1997) along with the increased photochemical activity due to the high insolation during this season may favor the accumulation of fine aerosols that can explain the high fine particle loads during July-October in comparison with November-January. In addition, the presence of these fine aerosol particles may be favored by pollution transport from Europe and coastal urban industrial areas in northeast Africa. In this sense, the highest fine mode aerosol optical depth observed in October was associated with the increase in the frequency of air masses coming from European urban areas (see for example Fig. 4). The low aerosol loads registered in November-January can be explained by the high frequency of clean Atlantic air advection (70-100\%) and the absence of Saharan dust intrusions (Fig. 5c) as well as efficient wet removal aerosol processes due to cloudy conditions and precipitation in this period. These results highlight the important role of the large scale circulation on monthly aerosol variation over Alborán Island.

\subsection{Spatial variability of aerosol properties over western Mediterranean region}

AERONET data of level 2 from Alborán and three AERONET stations surrounding the island (see Fig. 1) obtained from 1 July 2011 to 23 January 2012 are considered in this study to investigate the spatial variation of aerosol optical properties over the western Mediterranean region. For analyzing the spatial aerosol variability we compared the aerosol data obtained over Alborán during 1 July 2011-23 January 2012 with those observed over these nearby sites using only time coincident measurements.

Temporal evolutions of daily mean values of $\delta_{\mathrm{a}}(500 \mathrm{~nm})$ from 1 July 2011 to 23 January 2012 obtained over Alborán Island and Málaga stations are shown in Fig. 6a. Daily mean data were calculated only from time coincident measurements for direct comparison. Málaga is located approx- 

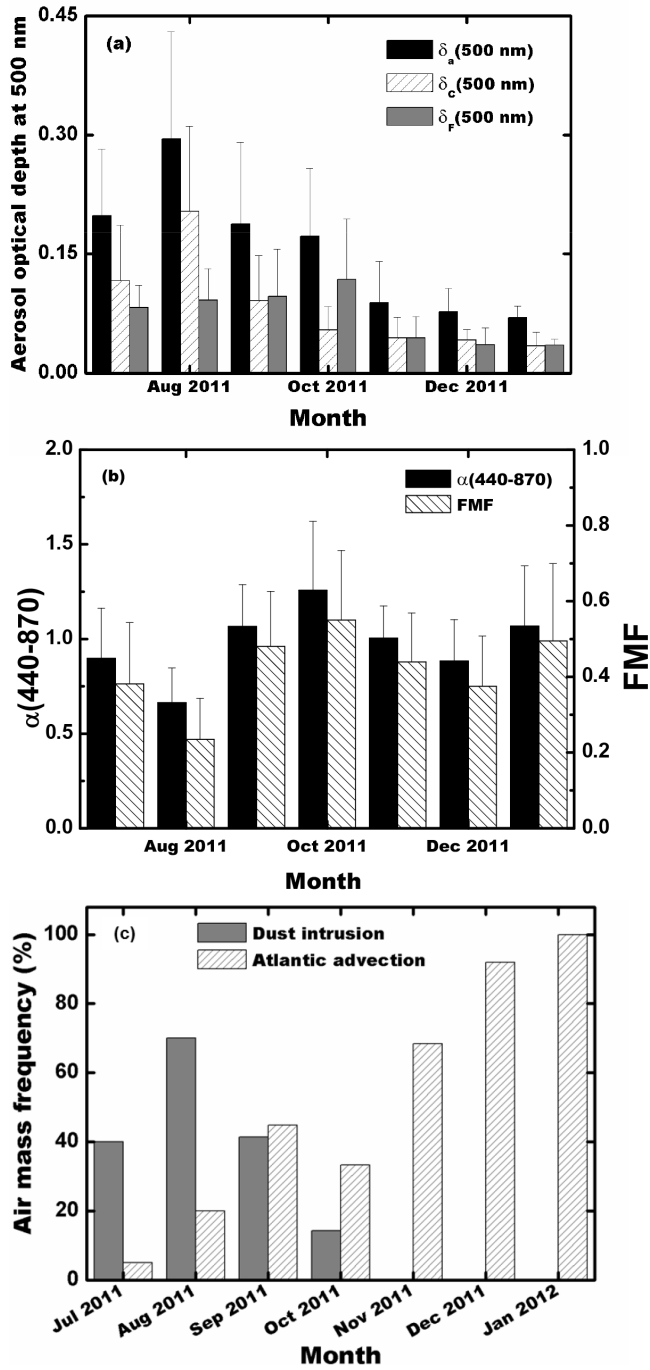

Figure 5. Monthly variations of (a) total, coarse and fine mode optical depths at $500 \mathrm{~nm}$ and (b) fine mode fraction and Ångstrom exponent in the range 440-870 nm obtained at Alborán Island from July 2011 to January 2012. The error bars are standard deviations. (c) Monthly relative frequency of Saharan dust intrusions and Atlantic air mass advections over Alborán Island from July 2011 to January 2012.

imately $150 \mathrm{~km}$ northwest of Alborán. The temporal variations of daily mean values of $\delta_{\mathrm{a}}(500 \mathrm{~nm})$ were similar for both sites on most days of the analyzed period, indicating similarities in the processes that control the aerosol load over both sites. In fact, high correlation in $\delta_{\mathrm{a}}(500 \mathrm{~nm})$ with correlation coefficient, $R$, of 0.75 between these two sites was found. Similar results were obtained when comparing $\delta_{\mathrm{a}}(500 \mathrm{~nm})$ over Alborán with those in Oujda $(R=0.8)$ and Palma de Mallorca $(R=0.6)$, Fig. 6b, c. However, large differences are also present on some days (e.g., on 8 August 2011 at Alboran Island we registered $\delta_{\mathrm{a}}(500 \mathrm{~nm})$ above 0.5 while at Málaga the values were below 0.1 ). These differ-
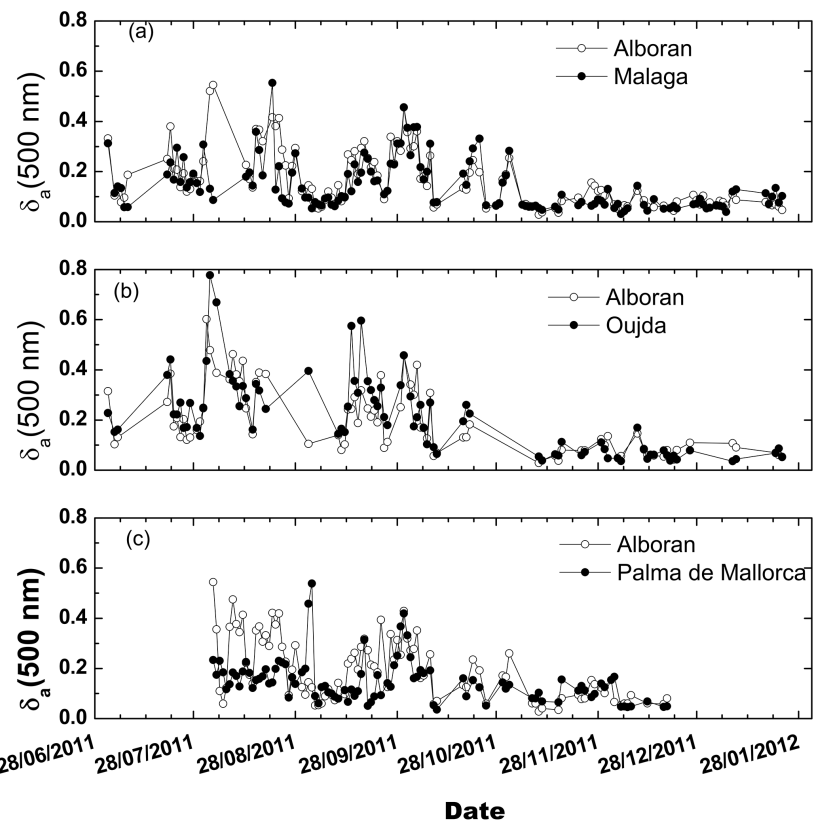

Figure 6. Temporal evolutions of daily mean values of $\delta_{\mathrm{a}}(500 \mathrm{~nm})$ from 1 July 2011 to 23 January 2012 obtained over (a) Alborán Island and Málaga, (b) Alborán Island and Oujda and (c) Alborán Island and Palma de Mallorca. Daily mean data were calculated only from time coincident measurements.

ences are due, in large part, to the differences in the times of occurrence and intensity of Saharan dust intrusions over these sites. In fact, the correlation in $\delta_{\mathrm{F}}(500 \mathrm{~nm})$ between Alborán Island and Málaga, $R=0.86$, was higher than the correlation in $\delta_{\mathrm{C}}(500 \mathrm{~nm}), R=0.65$. Similar results were obtained when comparing the aerosol properties over Alborán with those in Oujda $\left(R=0.82\right.$ for $\delta_{\mathrm{F}}(500 \mathrm{~nm})$ and $R=0.70$ for $\left.\delta_{C}(500 \mathrm{~nm})\right)$ and Palma de Mallorca $(R=0.67$ for $\delta_{\mathrm{F}}(500 \mathrm{~nm})$ and $R=0.32$ for $\left.\delta_{\mathrm{C}}(500 \mathrm{~nm})\right)$.

Table 2 shows average values of $\delta_{\mathrm{a}}(\lambda), \alpha(440-870)$, $\delta_{\mathrm{F}}(500 \mathrm{~nm})$ and FMF as well as the number of measurement days for each comparison (Alborán-Málaga, Alborán-Oujda and Alborán-Palma de Mallorca). Only days with coincident measurements obtained at Alborán and at each one of the additional AERONET stations from 1 July 2011 to 23 January 2012 were used for direct comparisons. For $\lambda>500 \mathrm{~nm}$, values of $\delta_{a}(\lambda)$ were slightly larger over Alborán than over Málaga (Table 2). Indeed, the mean $\delta_{\mathrm{a}}(1020 \mathrm{~nm})$ value obtained at Alborán was $35 \%$ larger than that observed over Málaga. This indicates that the coarse particles levels were significantly larger over Alborán in comparison with Málaga during the analyzed period. In fact, the mean $\delta_{\mathrm{C}}(500 \mathrm{~nm})$ for the entire analyzed period was slightly higher $(0.09 \pm 0.08)$ at Alborán in comparison with Málaga $(0.06 \pm 0.05)$. The lower coarse particles load over Málaga as compared to Alborán is likely due to the higher frequency of Saharan dust outbreaks over Alborán as compared to Málaga and also to dust deposition in its way from Alborán to Málaga. On the 
Table 2. Average values and standard deviations of $\delta_{\mathrm{a}}(\lambda), \alpha(440-870), \delta_{\mathrm{F}}(500 \mathrm{~nm})$ and FMF from 1 July 2011 to 23 January 2012 for Alborán Island, Málaga, Oujda and Palma de Mallorca. Only days with coincident measurements at Alborán and at each one of the additional AERONET stations are used for direct comparison.

\begin{tabular}{lrrrrrr}
\hline & Alborán & Málaga & Alborán & $\begin{array}{r}\text { Palma de } \\
\text { Mallorca }\end{array}$ & Alborán & Oujda \\
& & & & & \\
\hline$\delta_{\mathrm{a}}(1020 \mathrm{~nm})$ & $0.09 \pm 0.09$ & $0.06 \pm 0.05$ & $0.13 \pm 0.10$ & $0.06 \pm 0.04$ & $0.13 \pm 0.11$ & $0.16 \pm 0.17$ \\
$\delta_{\mathrm{a}}(870 \mathrm{~nm})$ & $0.10 \pm 0.09$ & $0.08 \pm 0.06$ & $0.14 \pm 0.11$ & $0.08 \pm 0.05$ & $0.14 \pm 0.11$ & $0.18 \pm 0.18$ \\
$\delta_{\mathrm{a}}(670 \mathrm{~nm})$ & $0.12 \pm 0.10$ & $0.09 \pm 0.07$ & $0.16 \pm 0.12$ & $0.10 \pm 0.06$ & $0.16 \pm 0.12$ & $0.19 \pm 0.18$ \\
$\delta_{\mathrm{a}}(500 \mathrm{~nm})$ & $0.16 \pm 0.11$ & $0.14 \pm 0.09$ & $0.20 \pm 0.13$ & $0.14 \pm 0.07$ & $0.20 \pm 0.13$ & $0.23 \pm 0.19$ \\
$\delta_{\mathrm{a}}(440 \mathrm{~nm})$ & $0.18 \pm 0.12$ & $0.16 \pm 0.10$ & $0.23 \pm 0.14$ & $0.18 \pm 0.09$ & $0.22 \pm 0.14$ & $0.25 \pm 0.19$ \\
$\delta_{\mathrm{a}}(380 \mathrm{~nm})$ & $0.21 \pm 0.13$ & $0.20 \pm 0.12$ & $0.26 \pm 0.15$ & $0.21 \pm 0.10$ & $0.25 \pm 0.15$ & $0.29 \pm 0.20$ \\
$\delta_{\mathrm{a}}(340 \mathrm{~nm})$ & $0.23 \pm 0.14$ & $0.23 \pm 0.13$ & $0.29 \pm 0.16$ & $0.24 \pm 0.11$ & $0.28 \pm 0.16$ & $0.30 \pm 0.20$ \\
$\alpha(440-870)$ & $0.9 \pm 0.4$ & $1.0 \pm 0.3$ & $0.8 \pm 0.4$ & $1.2 \pm 0.4$ & $0.8 \pm 0.4$ & $0.8 \pm 0.4$ \\
$\delta_{\mathrm{F}}(500 \mathrm{~nm})$ & $0.09 \pm 0.06$ & $0.09 \pm 0.06$ & $0.09 \pm 0.07$ & $0.09 \pm 0.06$ & $0.09 \pm 0.07$ & $0.09 \pm 0.06$ \\
FMF & $0.50 \pm 0.15$ & $0.53 \pm 0.13$ & $0.47 \pm 0.18$ & $0.60 \pm 0.14$ & $0.47 \pm 0.19$ & $0.47 \pm 0.19$ \\
Number of & 141 & 141 & 93 & 93 & 101 & 101 \\
coincident days & & & & & & \\
\hline
\end{tabular}

other hand, for $\lambda<500 \mathrm{~nm}$, the mean value of $\delta_{\mathrm{a}}(\lambda)$ over Alborán was almost similar to that over Málaga (Table 2). It is interesting to note that the mean $\delta_{F}(500 \mathrm{~nm})$ value for the entire studied period observed over Alborán $(0.09 \pm 0.06)$ was similar to that obtained $(0.09 \pm 0.06)$ over the Málaga urban coastal site, suggesting similar concentrations of fine particles over both sites. This result is quite surprising because Málaga is a coastal city with significant local anthropogenic emissions in comparison to Alborán where there are no local anthropogenic activities. As we commented before, Alborán Island is located near an important shipping route and hence it is expected to be highly influenced by ship emissions. Thus, these results suggest that emissions from ships and/or from urban-industrial areas in Mediterranean countries could play in Alborán a similar role to that played by anthropogenic particles in Málaga. Further studies using chemical analysis of particles sampled in situ are needed to evaluate this hypothesis.

The comparison of the aerosol properties obtained at $\mathrm{Ou}-$ jda and Alborán Island is also shown in Table 2. In this case, the $\delta_{\mathrm{a}}(\lambda)$ at all wavelengths were lower at Alborán than at Oujda, indicating lower aerosol concentrations over Alborán. However, $\delta_{\mathrm{F}}(500 \mathrm{~nm})$ was similar over Oujda and Alborán (Table 2), indicating similar fine particle loading over both sites. This result is again surprising because Oujda is an urban site with significant local anthropogenic emissions in comparison to Alborán Island where there is no local anthropogenic activities. These results also point to the significant role that anthropogenic emissions from traffic ships and/or Mediterranean countries may play over Alborán. On the other hand, $\delta_{\mathrm{C}}(500 \mathrm{~nm})$ obtained over Oujda $(0.14 \pm 0.15)$ was higher than that observed over Alborán $(0.11 \pm 0.10)$, indicating higher coarse particle concentrations over Oujda. The large coarse particle load over Oujda may result from its proximity to dust sources and local dust resuspension.
The mean $\delta_{\mathrm{a}}(\lambda)$ values at all wavelengths over Alborán were higher than those observed over Mallorca, especially at the larger wavelengths which are more influenced by coarse particles (Table 2). However, as in the other cases, $\delta_{\mathrm{F}}(500 \mathrm{~nm})$ was very similar over both sites (Table 2$)$ in spite of the large distance (about $650 \mathrm{~km}$ ) separating the sites and site characteristic differences. These results suggest homogeneous spatial distribution of fine particle loads over the four studied sites in spite of the large differences in local sources. On the other hand, the observed decrease in $\delta_{\mathrm{a}}(500 \mathrm{~nm})$ from south (Alborán) to north (Mallorca) may be attributed to the proximity of Alborán Island to the dust sources in north Africa as compared to Mallorca. A gradient in dust load from south to north in western Mediterranean has also been reported by other authors (e.g., Moulin et al., 1998; Barnaba and Gobbi, 2004). Overall, based on the above comparisons it may be concluded that $\delta_{C}(\lambda)$ showed a south-to-north decrease in this region of western Mediterranean, while the fine mode aerosol optical depth was fairly similar over these sites.

\subsection{Variability of aerosol properties during a MAN cruise}

From 26 July to 13 November 2011 the Maritime Aerosol Network acquired measurements over the whole Mediterranean Sea, Black Sea and Atlantic Ocean from the ship Nautilus 11. Figure 7 shows $\delta_{\mathrm{a}}(500 \mathrm{~nm}), \delta_{\mathrm{F}}(500 \mathrm{~nm}), \delta_{\mathrm{C}}(500 \mathrm{~nm})$ and FMF obtained during this cruise. The measurements made over the Mediterranean Sea were divided (on the basis of the differences in the aerosol sources and air masses affecting each area) into three regions: western, central and eastern Mediterranean. As can be seen from Fig. 7, all the analyzed aerosol properties showed large variability with no evident pattern during the cruise period. This large variability in aerosol properties during this cruise can be explained 

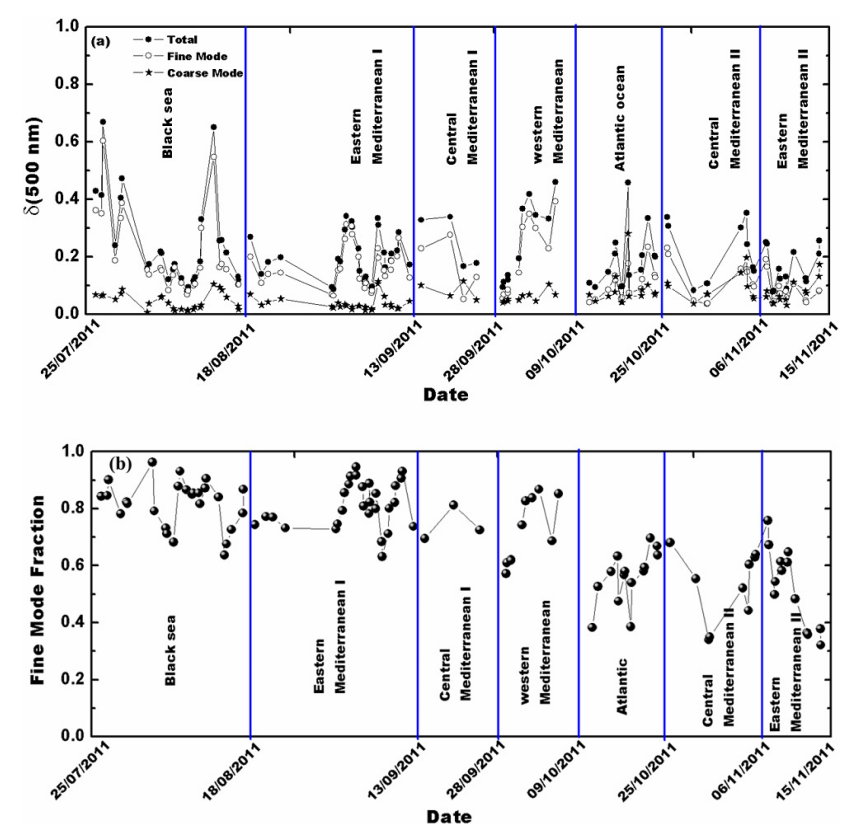

Figure 7. Temporal evolutions of $\delta_{\mathrm{a}}(500 \mathrm{~nm}), \delta_{F}(500 \mathrm{~nm})$, $\delta_{\mathrm{C}}(500 \mathrm{~nm})$, and FMF obtained onboard the Nautilus ship. The data belong to the Maritime Aerosol Network (MAN) and were acquired between 26 July and 13 November 2011.

by the different aerosol sources and air masses that affected each region during the measurement period (see below). For the entire cruise period, the $\delta_{\mathrm{a}}(500 \mathrm{~nm})$ varied from 0.08 to 0.70 with a mean value of $0.22 \pm 0.12$. On the other hand, $\delta_{F}(500 \mathrm{~nm})$ also showed large variability and ranged between 0.04 and 0.60 with a mean value of $0.16 \pm 0.10$ while $\delta_{\mathrm{C}}(500 \mathrm{~nm})$ fluctuated within the range $0.01-0.30$ with mean value of $0.06 \pm 0.04$. For $85 \%$ of the measurements, the fine mode fraction was in the range $0.52-0.96$, indicating the predominance of situations dominated by fine mode particles during this cruise.

The highest $\delta_{\mathrm{a}}(500 \mathrm{~nm})$ values ranging from 0.20 to 0.46 with a mean value of $0.35 \pm 0.09$ were observed over the western Mediterranean Sea during the cruise period 28 September-08 October (Table 3). Also, $\delta_{\mathrm{F}}(500 \mathrm{~nm})$ values were highest (varying in the range of $0.14-0.40$ with a mean value of $0.29 \pm 0.09$ ) over the western Mediterranean. These high aerosol loads were associated with high FMF values in the range $0.70-0.87$, which show the predominance of fine anthropogenic particles over this area during this period (Fig. 7b). According to the back trajectory analyses, the air masses that affected the western Mediterranean region during this period come from European urban-industrial areas which explains the observed large values of $\delta_{\mathrm{a}}(500 \mathrm{~nm})$ and the predominance of fine mode particles (see for example Fig. 4c). The aerosol loads were also relatively high over the Black Sea $\left(\delta_{\mathrm{a}}(500 \mathrm{~nm})\right.$, ranging from 0.08 to 0.68 with a mean value of $0.25 \pm 0.16$ during 26 July-15 August cruise period) and were strongly dominated by fine particles as showed by FMF values ranging from 0.64 to 0.94 . The large values of $\delta_{\mathrm{a}}(500 \mathrm{~nm})$ and those of $\delta_{\mathrm{F}}(500 \mathrm{~nm})\left(\delta_{F}(500 \mathrm{~nm})\right.$ in the range 0.07-0.60) and the predominance of the fine mode over the Black Sea during this cruise period was associated, according to the HYSPLIT back trajectory analyses, with air masses coming from northeastern Europe (Figure not shown); this region has been identified as a strong source of pollutants and biomass burning particles during summer (e.g., Barnaba and Gobbi, 2004). In contrast, the lowest $\delta_{\mathrm{a}}(500 \mathrm{~nm})$ values (varying in the range $0.08-0.26$ with mean value of $0.14 \pm 0.06$ ) were observed over the eastern Mediterranean at the end of the cruise (5-13 November). These low $\delta_{\mathrm{a}}(500 \mathrm{~nm})$ values were associated with FMF ranging between 0.30 and 0.64 , showing a predominance of coarse aerosol over this area during this period. It is worth noting that the aerosol loads over the eastern Mediterranean during 5-13 November decreased drastically in comparison with the aerosol levels observed in the same region during the cruise period from 18 August to 13 September (Table 3). The decrease was more pronounced for the fine particle load; $\delta_{F}(500 \mathrm{~nm})$ decreased from $0.16 \pm 0.07$ in the first measurements over the eastern Mediterranean to $0.07 \pm 0.02$ in the last ones. In contrast, $\delta_{\mathrm{C}}(500 \mathrm{~nm})$ showed an increase from $0.04 \pm 0.02$ during 18 August-12 September to $0.08 \pm 0.04$ during 5-13 November. This drastic change may be explained by the seasonal changes in the meteorological conditions. In this sense, the last measurements over the eastern Mediterranean Sea were obtained during the end of autumn when aerosol wet deposition is more effective and secondary aerosol formation is less important than in summer, which may explain the lower aerosol loads observed at the end of the expedition.

\section{Conclusions}

AERONET sun photometer measurements obtained over Alborán Island and three adjacent sites in the western Mediterranean were analyzed in order to investigate the temporal and spatial variations of columnar aerosol properties over this poorly explored region.

Within the analyzed period the daily average values of $\delta_{\mathrm{a}}(500 \mathrm{~nm})$ over Alborán Island ranged from 0.03 to 0.54 with a mean and standard deviation of $0.17 \pm 0.12$, indicating high aerosol load variation. The observed mean $\delta_{\mathrm{a}}(500 \mathrm{~nm})$ value over Alborán Island was significantly higher than reported for open oceanic areas not affected by long range aerosol transport $(0.06-0.08)$. The $\alpha(440-870)$ values were lower than 1 for $70 \%$ of the measurement days, suggesting that coarse particles dominated the aerosol population over the Alborán Island for the majority of the measurement days.

High aerosol loads over Alborán were mainly associated with desert dust transport from arid areas in North Africa and occasional advection of anthropogenic fine particles from central European urban-industrial areas. The aerosol opti- 
Table 3. Mean values of $\delta_{\mathrm{a}}(500 \mathrm{~nm}), \delta_{\mathrm{F}}(500 \mathrm{~nm}), \delta_{\mathrm{C}}(500 \mathrm{~nm}), \alpha(440-870)$ and FMF obtained over the Black Sea; the western, central and eastern Mediterranean Sea; and the Atlantic Ocean during the Nautilus ship cruise from 26 July to 13 November 2011.

\begin{tabular}{lccccr}
\hline Region & $\delta_{\mathrm{a}}(500 \mathrm{~nm})$ & $\delta_{\mathrm{F}}(500 \mathrm{~nm})$ & $\delta_{\mathrm{C}}(500 \mathrm{~nm})$ & $\alpha(440-870)$ & FMF \\
\hline $\begin{array}{l}\text { Black Sea } \\
\text { (26 July-15 August) }\end{array}$ & $0.25 \pm 0.16$ & $0.21 \pm 0.14$ & $0.04 \pm 0.03$ & $1.76 \pm 0.30$ & $0.82 \pm 0.08$ \\
$\begin{array}{l}\text { Eastern Mediterranean I } \\
\text { (18 August-12 September) }\end{array}$ & $0.20 \pm 0.08$ & $0.16 \pm 0.07$ & $0.04 \pm 0.02$ & $1.74 \pm 0.20$ & $0.81 \pm 0.08$ \\
$\begin{array}{l}\text { Central Mediterranean I } \\
\text { (13-28 September) }\end{array}$ & $0.18 \pm 010$ & $0.12 \pm 0.09$ & $0.06 \pm 0.03$ & $1.27 \pm 0.40$ & $0.66 \pm 0.08$ \\
$\begin{array}{l}\text { Western Mediterranean } \\
\text { (28 September-8 October) }\end{array}$ & $0.35 \pm 0.09$ & $0.29 \pm 0.09$ & $0.07 \pm 0.02$ & $1.50 \pm 0.13$ & $0.80 \pm 0.07$ \\
$\begin{array}{l}\text { Atlantic Ocean } \\
\text { (9-19 October) }\end{array}$ & $0.19 \pm 0.10$ & $0.11 \pm 0.05$ & $0.09 \pm 0.06$ & $1.08 \pm 0.25$ & $0.56 \pm 0.09$ \\
$\begin{array}{l}\text { Central Mediterranean II } \\
\text { (25 October-5 November) }\end{array}$ & $0.22 \pm 0.10$ & $0.13 \pm 0.07$ & $0.09 \pm 0.04$ & $1.05 \pm 0.30$ & $0.57 \pm 0.13$ \\
$\begin{array}{l}\text { Eastern Mediterranean II } \\
\text { (5-13 November) }\end{array}$ & $0.14 \pm 0.06$ & $0.07 \pm 0.02$ & $0.08 \pm 0.04$ & $0.90 \pm 0.35$ & $0.49 \pm 0.12$ \\
\hline
\end{tabular}

cal depth values of fine mode during dust events were also relatively high (for this remote site), suggesting that the fine mode particles also have considerable influence on optical properties during these dust events. Background maritime conditions over Alborán characterized by low aerosol load and Ångström exponent $\left(\delta_{a}(500 \mathrm{~nm})<0.15\right.$ and $\alpha(440$ $870)<1$ ) were observed on about $40 \%$ of the measurement days during the analyzed period; almost all of these days were characterized by advection of clean Atlantic air masses over the study area.

The mean value of $\delta_{\mathrm{F}}(500 \mathrm{~nm})$ over Alborán Island was comparable to the observations over the other three nearby AERONET stations, suggesting homogeneous spatial distribution of fine particle loads over the four studied sites in spite of the large differences in local sources. A northward decreases in $\delta_{C}(\lambda)$ was found which was probably associated with increased desert dust deposition from south to north or decreased dust frequency from south to north.

Aerosol properties acquired on board the ship Nautilus 11 within Maritime Aerosol Network over the whole Mediterranean Sea, Black Sea and Atlantic Ocean from July to November 2011 showed large variability and no evident pattern was found. In $85 \%$ of the measurements, the fine mode fraction was in the range 0.52-0.96, indicating the predominance of fine mode particles over the cruise areas during the monitoring period. The highest $\delta_{\mathrm{a}}(500 \mathrm{~nm})$ and $\delta_{\mathrm{F}}(500 \mathrm{~nm})$ mean values of $0.35 \pm 0.09$ and $0.29 \pm 0.09$ during the cruise period were observed over the western Mediterranean Sea, which were related to polluted air masses coming from European urban-industrial areas. In contrast, the lowest $\delta_{\mathrm{a}}(500 \mathrm{~nm}$ ) values (mean value of $0.14 \pm 0.06$ ) during this cruise were observed over the eastern Mediterranean Sea on the final days of the cruise in autumn, when aerosol wet deposition is more effective and secondary aerosol formation is less important than in summer.
Acknowledgements. This work was supported by the Andalusia Regional Government through projects P12-RNM-2409 and P10RNM-6299, by the Spanish Ministry of Science and Technology through projects CGL2010-18782, and CGL2013-45410-R; and by the EU through ACTRIS project (EU INFRA-2010-1.1.16-262254). CIMEL Calibration was performed at the AERONET-EUROPE calibration center, supported by ACTRIS (European Union Seventh Framework Program (FP7/2007-2013) under grant agreement no. 262254. The authors gratefully acknowledge the outstanding support received from Royal Institute and Observatory of the Spanish Navy (ROA). The authors are grateful to the AERONET, MAN, and field campaign PIs for the production of the data used in this research effort. We would like to express our gratitude to the NASA Goddard Space Flight Center, NOAA Air Resources Laboratory and Naval Research Laboratory for the HYSPLIT model. We would like to acknowledge the constructive comments of A. Smirnov about the AERONET data. Finally, we also thank A. Kowalski for revising the manuscript.

Edited by: O. Dubovik

\section{References}

Alados-Arboledas, L., Lyamani, H., and Olmo, F. J.: Aerosol size properties at Armilla, Granada (Spain), Q. J. R. Meteorol. Soc., 129, 1395-1413, 2003.

Alados-Arboledas, L., Muller, D., Guerrero-Rascado, J. L., NavasGuzman, F., Perez-Ramirez, D., and Olmo, F. J.: Optical and microphysical properties of fresh biomass burning aerosol retrieved by Raman lidar, and star-and sun-photometry, Geophys. Res. Lett., 38, L01807, doi:10.1029/2010g1045999, 2011.

Antón, M., Valenzuela, A., Cazorla, A., Gil, L. E., FernandezGalvez, J., Lyamani, H., Foyo-Moreno, I., Olmo, F. J., and Alados-Arboledas, L.: Global and diffuse shortwave irradiance during a strong desert dust episode at Granada (Spain), Atmos. Res., 118, 232-239, doi:10.1016/j.atmosres.2012.07.007, 2012. 
Balis, D., Amiridis, V., Zerefos, C., Gerasopoulos, E., Andreae, M. O., Zanis, P., Kazantzidis, A., Kazadzis, S., and Papayannis, A.: Raman lidar and Sunphotometric measurements of aerosol optical properties over Thessaloniki, Greece during a biomass burning episode, Atmos. Environ., 37, 4529-4538, 2003.

Barnaba, F. and Gobbi, G. P.: Aerosol seasonal variability over the Mediterranean region and relative impact of maritime, continental and Saharan dust particles over the basin from MODIS data in the year 2001, Atmos. Chem. Phys., 4, 2367-2391, doi:10.5194/acp-4-2367-2004, 2004.

Becagli, S., Sferlazzo, D. M., Pace, G., di Sarra, A., Bommarito, C., Calzolai, G., Ghedini, C., Lucarelli, F., Meloni, D., Monteleone, F., Severi, M., Traversi, R., and Udisti, R.: Evidence for heavy fuel oil combustion aerosols from chemical analyses at the island of Lampedusa: a possible large role of ships emissions in the Mediterranean, Atmos. Chem. Phys., 12, 3479-3492, doi:10.5194/acp-12-3479-2012, 2012.

Boselli, A., Caggiano, R., Cornacchia, C., Madonna, F., Mona, L., Macchiato, M., Pappalardo, G., and Trippetta, S.: Multi year Sun photometer measurements for aerosol characterization in a Central Mediterranean site, Atmos. Res., 104-105, 98-110, doi:10.1016/j.atmosres.2011.08.002, 2012.

Di Biagio, C., di Sarra, A., and Meloni, D.: Large atmospheric shortwave radiative forcing by Mediterranean aerosols derived from simultaneous ground-based and spaceborne observations and dependence on the aerosol type and single scattering albedo, J. Geophys. Res., 115, D10209, doi:10.1029/2009JD012697, 2010.

Di Iorio, T., Sarra, A. D., Junkermann, W., Cacciani, M., Fiocco, G., and Fuà, D.: Tropospheric aerosols in the Mediterranean: 1. Microphysical and optical properties, J. Geophys. Res., 108, 4316, doi:10.1029/2002JD002815, 2003.

Di Sarra, A., Pace, G., Meloni, D., De Silvestri, L., Piacentino, S., and Monteleone, F.: Surface shortwave radiative forcing of different aerosol types in the central Mediterranean, Geophys. Res. Lett., 35, L02714. doi:10.1029/2007GL032395, 2008.

Draxler, R. R. and Rolph, G. D.: HYSPLIT (Hybrid Single-Particle Lagrangian Integrated Trajectory). Model access via NOAA ARL READY website http://ready.arl.noaa.gov/HYSPLIT.php (last access: May 2012), 2003.

Dubovik, O., Holben, B., Eck, T. F., Smirnov, A., Kaufman, Y. J., King, M. D., Tanre, D., and Slutsker, I.: Variability of absorption and optical properties of key aerosol types observed in worldwide locations, J. Atmos. Sci., 59, 590-608, 2002.

Estellés, V., Martinez-Lozano, J. A., Utrillas, M. P., and Campanelli, M.: Columnar aerosol properties in Valencia (Spain) by groundbased Sun photometry, J. Geophys. Res.-Atmos., 112, D11201, doi:10.1029/2006jd008167, 2007.

Estellés, V., Campanelli, M., Smyth, T. J., Utrillas, M. P., and Martínez-Lozano, J. A.: Evaluation of the new ESR network software for the retrieval of direct sun products from CIMEL CE318 and PREDE POM01 sun-sky radiometers, Atmos. Chem. Phys., 12, 11619-11630, doi:10.5194/acp-12-11619-2012, 2012.

Formenti, P., Andreae, M., Andreae, T., Galani, E., Vasaras, A., Zerefos, C., Amiridis, V., Orlovsky, L., Karnieli, A.,Wendisch, M.,Wex, H., Holben, B., Maenhaut,W., and Lelieveld, J.: Aerosol optical properties and large-scale transport of air masses: observations at a coastal and a semiarid site in the eastern Mediter- ranean during summer 1998, J. Geophys. Res., 106, 9807-9826, doi:10.1029/2000JD900609, 2001.

Forster, P., Ramaswamy, V., Artaxo, P., Berntsen, T., Betts, R., Fahey, D. W., Haywood, J., Lean, J., Lowe, D. C., Myhre, G., Nganga, J., R. Prinn, Raga, G., Schulz, M., and Dorland, R. V.: Changes in Atmospheric Constituents and in Radiative Forcing, Climate Change 2007: The Physical Science Basis, Contribution of Working Group I to the Fourth Assessment Report of the Intergovernmental Panel on Climate Change, edited by: Solomon, S., Qin, D., Manning, M., Chen, Z., Marquis, M., Averyt, K. B., Tignor, M., and Miller, H. L., Cambridge University Press, Cambridge, UK and New York, NY, USA, 2007.

Fotiadi, A., Hatzianastassiou, N., Drakakis, E., Matsoukas, C., Pavlakis, K. G., Hatzidimitriou, D., Gerasopoulos, E., Mihalopoulos, N., and Vardavas, I.: Aerosol physical and optical properties in the Eastern Mediterranean Basin, Crete, from Aerosol Robotic Network data, Atmos. Chem. Phys., 6, 53995413, doi:10.5194/acp-6-5399-2006, 2006.

Foyo-Moreno I., Alados, I., Antón, M., Fernández-Gálvez, J., Cazorla, A., and Alados-Arboledas, L.: Estimating aerosol characteristics from solar irradiance measurements at an urban location in southeastern Spain. J. Geophys. Res., 119, 1845-1859, doi:10.1002/2013JD020599, 2014.

Gerasopoulos, E., Andreae, M. O., Zerefos, C. S., Andreae, T. W., Balis, D., Formenti, P., Merlet, P., Amiridis, V., and Papastefanou, C.: Climatological aspects of aerosol optical properties in Northern Greece, Atmos. Chem. Phys., 3, 2025-2041, doi:10.5194/acp-3-2025-2003, 2003.

Haywood, J. and Boucher, O.: Estimates of the direct and indirect radiative forcing due to tropospheric aerosols: a review, Rev. Geophys., 38, 513-543, 2000.

Haywood, J. M. and Shine K. P.: Multi-spectral calculations of the direct radiative forcing of tropospheric sulphate and soot aerosols using a column model, Q. J. Roy. Meteor. Soc., 123, 1907-1930, 1997.

Holben, B. N., Eck, T. F., Slutsker, I., Tanre, D., Buis, J. P., Setzer, A., Vermote, E., Reagan, J. A., Kaufman, Y. J., Nakajima, T., Lavenu, F., Jankowiak, I., and Smirnov, A.: AERONET - A federated instrument network and data archive for aerosol characterization, Remote Sens. Environ., 66, 1-16, 1998.

Horvath, H., Alados Arboledas, L., Olmo, F.J., Jovanovic, O., Gangl, M., Sanchez, C., Sauerzopf, H., and Seidl, S.: Optical characteristics of the aerosol in Spain and Austria and its effect on radiative forcing, J. Geophys. Res., 107, 4386, doi:10.1029/2001JD001472, 2002.

Kaufman, Y. J., Wald, A. E., Remer, L. A., Gao, B. C., Li, R. R., and Flynn, L.: The MODIS 2.1-mu m channel - Correlation with visible reflectance for use in remote sensing of aerosol, IEEE T. Geosci. Remote. Sens., 35, 1286-1298, 1997.

Kaufman, Y. J., Koren, I., Remer, L. A., Rosenfeld, D., and Rudich, Y.: The effect of smoke, dust, and pollution aerosol on shallow cloud development over the Atlantic Ocean, P. Natl. Acad. Sci. USA, 102, 11207-11212, 2005.

Knobelspiesse, K. D., Pietras, C., Fargion, G. S., Wang, M. H., Frouin, R., Miller, M. A., Subramaniam, S., and Balch, W. M. : Maritime aerosol optical thickness measured by handheld sunphotometers, Remote Sens. Environ., 93, 87-106, 2004. 
Kubilay, N., Cokacar, T., and Oguz T.: Optical properties of mineral dust outbreaks over the north-eastern Mediterranean, J. Geophys. Res., 108, 4666, doi:10.1029/2003JD003798, 2003.

Lelieveld, J., Berresheim, H., Borrmann, S., Crutzen, P. J., Dentener, F. J., Fischer, H., de Gouw, J., Feichter, J., Flatau, P., Heland, J., Holzinger, R., Korrmann, R., Lawrence, M., Levin, Z., Markowicz, K., Mihalopoulos, N., Minikin, A., Ramanathan, V.,de Reus, M., Roelofs, G.-J., Scheeren, H. A., Sciare, J., Schlager, H., Schultz, M., Siegmund, P., Steil, B., Stephanou, E., Stier, P., Traub, M., Williams, J., and Ziereis, H.: Global air Pollution crossroads over the Mediterranean, Science, 298, 794799, 2002.

Lyamani, H., Olmo, F. J., and Alados-Arboledas, L.: Saharan dust outbreak over southeastern Spain as detected by sun photometer, Atmos. Environ., 39, 7276-7284, doi:10.1016/j.atmosenv.2005.09.011, 2005.

Lyamani, H., Olmo, F. J., Alcantara, A., and Alados-Arboledas, L.: Atmospheric aerosols during the 2003 heat wave in southeasternSpain I: Spectral optical depth, Atmos. Environ., 40, 6453-6464, doi:10.1016/j.atmosenv.2006.04.048, 2006a.

Lyamani, H., Olmo, F. J., Alcantara, A., and Alados-Arboledas, L.: Atmospheric aerosols during the 2003 heat wave insoutheastern Spain II: Microphysical columnar properties and radiative forcing, Atmos. Environ., 40, 6465-6476, doi:10.1016/j.atmosenv.2006.04.047, 2006b.

Mallet, M., Roger, J. C., Despiau, S., Dubovik, O., and Putaud, J. P.: Microphysical and optical properties of aerosol particles in urban zone during ESCOMPTE, Atmos. Res., 69, 73-97, 2003.

Mallet, M., Dubovik, O., Nabat, P., Dulac, F., Kahn, R., Sciare, J., Paronis, D., and Léon, J. F.: Absorption properties of Mediterranean aerosols obtained from multi-year ground-based remote sensing observations, Atmos. Chem. Phys., 13, 9195-9210, doi:10.5194/acp-13-9195-2013, 2013.

Markowicz, K. M., Flatau, P. J., Ramana, M. V., and Crutzen, P. J.: Absorbing mediterranean aerosols lead to a large reduction in the solar radiation at the surface, Geophys. Res. Lett., 29, 1968, doi:10.1029/2002GL015767, 2002.

Meloni, D., di Sarra, G., Biavati, G., DeLuisi, J. J., Monteleone, F., Pace, G., Piacentino, S., and Sferlazzo, D. M.: Seasonal behaviour of Saharan dust events at the Mediterranean island of Lampedusa in the period 1999-2005, Atmos. Environ., 41, 3041-3056, 2007.

Meloni, D., di Sarra, A., Monteleone, F., Pace, G., Piacentino, S., and Sferlazzo, D. M.: Seasonal transport patterns of intense Saharan dust events at the Mediterranean island of Lampedusa, Atmos. Res., 88, 134-148, 2008.

Millán M. M., Salvador, R., Mantilla, E., and Kallos, G.: Photooxidant dynamics in the Mediterranean basin in summer: results from European research projects., Geophys. Res. Lett., 102, 8811-8823, 1997.

Moulin, C., Lambert, C. E., Dayan, U., Masson, V., Ramonet, M., Bousquet, P., Legrand, M., Balkanski, Y. J., Guelle, W., Marticorena, B., Bergametti, G., and Dulac, F.: Satellite climatology of African dust transport in the Mediterranean atmosphere, J. Geophys. Res., 103, 13137-13144, 1998.

O’Neill, N. T., Eck, T. F., Smirnov, A., Holben, B. N., and Thulasiraman, S.: Spectral discrimination of coarse and fine mode optical depth, J. Geophys. Res.-Atmos., 108, 4559, doi:10.1029/2002jd002975, 2003.
Pace, G., Meloni, D., and di Sarra, A.: Forest fire aerosol over the Mediterranean basin during summer 2003, J. Geophys. Res.Atmos., 110, D21202, doi:10.1029/2005jd005986, 2005.

Pace, G., di Sarra, A., Meloni, D., Piacentino, S., and Chamard, P.: Aerosol optical properties at Lampedusa (Central Mediterranean). 1. Influence of transport and identification of different aerosol types, Atmos. Chem. Phys., 6, 697-713, doi:10.5194/acp-6-697-2006, 2006.

Pandolfi, M., Gonzalez-Castanedo, Y., Alastuey, A., de la Rosa, J. D., Mantilla, E., Sánchez de la Campa, A., Querol, X., Pey, J., Amato, F., and Moreno, T.: Source apportionment of $\mathrm{PM}_{10}$ and $\mathrm{PM}_{2.5}$ at multiple sites in the strait of Gibraltar by PMF: impact of shipping emissions, Environ. Sci. Pollut Res., 18, 260-269, doi:10.1007/s11356-010-0373-4, 2011.

Papadimas C. D., Hatzianastassiou, N., Mihalopoulos, N., Querol, X., and Vardavas, I.: Spatial and temporal variability in aerosol properties over the Mediterranean basin based on 6 yr (2000-2006) MODIS data, J. Geophys. Res., 113, D11205, doi:10.1029/2007JD009189, 2008.

Papadimas, C. D., Hatzianastassiou, N., Matsoukas, C., Kanakidou, M., Mihalopoulos, N., and Vardavas, I.: The direct effect of aerosols on solar radiation over the broader Mediterranean basin, Atmos. Chem. Phys., 12, 7165-7185, doi:10.5194/acp-12-71652012, 2012.

Pérez-Ramírez, D., Lyamani, H., Olmo, F. J., Whiteman, D. N., and Alados-Arboledas, L.: Columnar aerosol properties from sunand-star photometry: statistical comparisons and day-to-night dynamic, Atmos. Chem. Phys., 12, 9719-9738, doi:10.5194/acp12-9719-2012, 2012.

Saha, A., Mallet, M., Roger, J. C., Dubuisson, P., Piazzola, J., and Despiau, S.: One year measurements of aerosol optical properties over an urban coastal site: Effect on local direct radiative forcing, Atmos. Res., 90, 195-202, 2008.

Sayer, A. M., Smirnov, A., Hsu, N. C., and Holben, B. N.: A pure marine aerosol model, for use in remote sensing applications, J. Geophys. Res., 117, D05213, doi:10.1029/2011JD016689, 2012a.

Sayer, A. M., Smirnov, A., Hsu, N. C., Munchak, L. A., and Holben, B. N.: Estimating marine aerosol particle volume and number from Maritime Aerosol Network data, Atmos. Chem. Phys., 12, 8889-8909, doi:10.5194/acp-12-8889-2012, 2012b.

Smirnov, A., Holben, B. N., Kaufman, Y. J., Dubovik, O., Eck, T. F., Slutsker, I., Pietras, C., and Halthore, R.: Optical properties of atmospheric aerosol in maritime environments, J. Atmos. Sci. 59, 501-523, 2002.

Smirnov, A., Holben, B. N., Dubovik, O., Frouin, R., Eck, T. F., and Slutsker I.: Maritime component in aerosol optical models derived from Aerosol Robotic Network data, J. Geophys. Res., 108, 4033, doi:10.1029/2002JD002701, 2003.

Smirnov, A., Holben, B. N., Slutsker, I., Giles, D. M., Mc-Clain, C. R., Eck, T. F., Sakerin, S. M., Macke, A., Croot, P., Zibordi, G., Quinn, P. K., Sciare, J., Kinne, S., Harvey, M., Smyth, T. J., Piketh, S., Zielinski, T., Proshuninsky, A., Goes, J. I., Nelson, N. B., Larouche, P., Radionov, V. F., Goloub, P., Moorthy, K. K., Matarresse, R., Robertson, E. J., and Jourdin, F.: Maritime Aerosol Network as a component of Aerosol Robotic Network, J. Geophys. Res., 112, D06204, doi:10.1029/2008JD011257, 2009.

Smirnov, A., Holben, B. N., Giles, D. M., Slutsker, I., O’Neill, N. T., Eck, T. F., Macke, A., Croot, P., Courcoux, Y., Sakerin, S. M., 
Smyth, T. J., Zielinski, T., Zibordi, G., Goes, J. I., Harvey, M. J., Quinn, P. K., Nelson, N. B., Radionov, V. F., Duarte, C. M., Losno, R., Sciare, J., Voss, K. J., Kinne, S., Nalli, N. R., Joseph, E., Krishna Moorthy, K., Covert, D. S., Gulev, S. K., Milinevsky, G., Larouche, P., Belanger, S., Horne, E., Chin, M., Remer, L. A., Kahn, R. A., Reid, J. S., Schulz, M., Heald, C. L., Zhang, J., Lapina, K., Kleidman, R. G., Griesfeller, J., Gaitley, B. J., Tan, Q., and Diehl, T. L.: Maritime aerosol network as a component of AERONET - first results and comparison with global aerosol models and satellite retrievals, Atmos. Meas. Tech., 4, 583-597, doi:10.5194/amt-4-583-2011, 2011.

Sumner, G., Homar, V., and Ramis, C.: Precipitation seasonality in Eastern and Southern coastal Spain, Int. J. Climatol., 21, 219247,2001

Valenzuela, A., Olmo, F. J., Lyamani, H., Antón, M., Quirantes, A., and Alados-Arboledas, L.: Classification of aerosol radiative properties during African desert dust intrusions over southeastern Spain by sector origins and cluster analysis, J. Geophys. Res.Atmos., 117, D06214, doi:10.1029/2011JD016885, 2012a.
Valenzuela, A., Olmo, F. J., Lyamani, H., Antón, M., Quirantes, A., and Alados-Arboledas, L.: Aerosol radiative forcing during African desert dust events (2005-2010) over Southeastern Spain, Atmos. Chem. Phys., 12, 10331-10351, doi:10.5194/acp12-10331-2012, 2012b.

Viana, M., Amato, F., Alastuey, A., Querol, X., Moreno, T., Dos Santos, S. G., Herce, M. D., and Fernández-Patier, R.: Chemical tracers of particulate emissions from commercial shipping, Environ. Sci. Technol., 43, 7472-7477, 2009.

Thieuleux, F., Moulin, C., Breon, F. M., Maignan, F., Poitou, J., and Tanre D.: Remote sensing of aerosols over the oceans using MSG/SEVIRI imagery, Ann. Geophys., European Geosciences Union (EGU), 23, 3561-3568, 2005.

Toledano, C., Cachorro, V. E., Berjon, A., de Frutos, A. M., Sorribas, M., de la Morena, B. A., and Goloub, P.: Aerosol optical depth and Ångstrom exponent climatology at El Arenosillo AERONET site (Huelva, Spain), Q. J. Roy. Meteorol. Soc., 133, 795-807, doi:10.1002/qj.54, 2007. 